\title{
The Effect of Indigenous Root-Nodulating Bacteria on Nodulation and Growth of Faba Bean (Vicia Faba) in the Low-Input Agricultural Systems of Tigray Highlands, Northern Ethiopia
}

\section{Alemayehu Workalemahu}

Department of Biology, College of Natural and Computational Sciences, Mekelle University, P.O. Box. 3072, Mekelle, Ethiopia (alemayehuwork@yahoo.co.uk)

\begin{abstract}
This study was initiated to isolate and characterize indigenous rhizobia nodulating faba bean, and evaluate symbiotic characteristics between the crop and the rhizobia in major faba bean producing areas in Tigray highlands. Field crops were also surveyed for nodulation in selected sites of seven (7) faba bean growing districts. A total of 44 rhizobial strains were isolated and their symbiotic properties (nodule number, fresh weight, color and plant growth) were recorded. A total of 12 strains with good symbiotic properties were characterized for their morphological and physiological traits on Yeast Extract Manitol Agar (YMA) medium. The result of the study showed the presence of diversity in morphological, physiological and symbiotic properties among the rhizobial strains. There was statistically significant difference in nodule number, fresh weight and shoot height $(p<0.05)$ and great variation in nodule color within and among the districts. Nodulation status of the field crops was poor except Ofla, D/Temben and Alaje districts. Though the presence of diversity among the strains revealed the possibility of getting potentially effective adaptable rhizobial strains that enhance faba bean productivity, the weak symbiotic properties observed during isolation and nodulation status survey might partly be responsible for yield variation and reduction in low input cropping systems of Tigray. Hence, studies on a need for inoculation and factors responsible for poor nodulation need to be undertaken to realize the role of biological nitrogen fixation in Tigray cropping systems.
\end{abstract}

Key words: Biological nitrogen fixation, Faba bean, Nodulation, Rhizobia, Symbiotic Effectiveness, Tigray.

\section{INTRODUCTION}

Ethiopia is one of the largest faba bean producing countries in the world only second to China (Hawitin and Hebblewaite, 1993). The country is considered as the secondary center of diversity and also one of the nine major agro-geographical production regions of faba bean (Asfaw Telaye et al., 1994). Faba bean is grown as field crop throughout the highlands and is most common in Wayena Dega between the altitudes $1800 \mathrm{~m}$ a.s.1 and $2400 \mathrm{~m}$ a.s.1 in Ethiopia (Asfaw Telaye, 1985). It serves as a daily food and as cash crop in many parts of the country (Hawitin and Hebblewaite, 1993). This legume crop is also known for its ability to form endosymbiotic association with root nodulating bacteria (rhizobia) group called Rhizobium leguminosarum bv. vicia. 
The compatible rhizobia induce root nodules, where atmospheric nitrogen $(\mathrm{N})$ is fixed. The number of the nodules and their rate of $\mathrm{N}$ fixation are determined by the effectiveness and the number of rhizobia in the soil (Lupwayi and Mkandawire, 1996; Amijee and Giller, 1998; Aynabeba et al., 2001). Furthermore, the level of effectiveness of rhizobia results in variation in the color of nodules (pink which is effective, white which is ineffective in nitrogen fixation). The variation in nodule number and color in turn induce variation in growth and yield of the host due to variation in fixed N (Lupwayi and Mkandawire, 1996; Amijee and Giller, 1998).

Faba bean in association with rhizobia can fix up to $120 \mathrm{~kg}$ nitrogen/ha (Danso, 1992). The contribution of the fixed nitrogen is a key factor in low input agricultural systems to sustain longterm soil fertility. This is especially important in areas where there is high farm land pressure and the fallow system is abandoned. Biologically fixed N (BNF) under such situations improves soil $\mathrm{N}$ content, in turn increases the yield of subsequent crops in cropping systems (Kiros Habtegebrial and Singh, 2006). Improved yield has been observed for wheat planted after faba bean in Ethiopia (Amanuel et al., 2000). However, accumulation of enough $\mathrm{N}$ and subsequent effect depends on the number and compatibility of rhizobia and mineral constraint that affect nodulation and N-fixation (Amijee and Giller, 1998; Zaharan, 1999; Aynabeba Adamu et al., 2001).

The effect of BNF also vary depending on survival of the rhizobial strains under different soil conditions like salinity, drought, acidity, soil temperature (Zaharan, 1999). O’Hara et al. (2002) reported that the abundance of diversity in the soil populations of rhizobia provides a large resource of natural germplasm to screen for desired characteristics present in the natural pool. This requires rigorous screening for efficient rhizobial strains with adaptation to different soil conditions (Zaharan, 1999). To achieve this, indigenous rhizobial strains can be characterized under different conditions in the laboratory and tested in the field for their effectiveness.

Faba bean is one of the most important food crops associated with farmers diet in the regional national state of Tigray. It is an inexpensive source of protein and cash crop to the farmers. It is also important in area coverage and production comparing to other pulse crops (Agricultural Bureau of Tigray). Its wide distribution in Tigray cropping systems highlights its importance in improving soil $\mathrm{N}$ content, yield of subsequent cereal crops and food security. Despite its importance in the region, its yield greatly varies among different production areas (Table.1) and is low comparing to national average yield of $1100 \mathrm{~kg} / \mathrm{ha}$ (EARO, 2000). 
Table 1. Production $(\mathrm{kg} / \mathrm{ha})$ of faba bean from major faba bean producing districts of Tigray (2003-2006).

\begin{tabular}{|lllllllll|}
\hline Year & Dagua & Ganta & Klte & $\begin{array}{c}\text { District } \\
\text { Saesie tsaeda } \\
\text { Temben }\end{array}$ & $\begin{array}{l}\text { Afeshum } \\
\text { Awlalo }\end{array}$ & $\begin{array}{l}\text { Atsbi } \\
\text { Wenberta }\end{array}$ & Alaje & Ofla \\
2003 & 600 & 480 & 470 & 400 & 420 & 300 & 1095 \\
$2004 / 05$ & 600 & n.a & 270 & n.a & 240 & 470 & 1500 \\
& & & & & & & \\
$2005 / 06$ & 860 & 500 & 540 & 920 & 900 & 1200 & 1400 \\
\hline
\end{tabular}

n.a $=$ data were not obtained from the source. Source: Agricultural Bureau of Tigray.

Though different factors may attribute for its yield variation and reduction, the most important reasons could be degradation of biotic resources such as rhizobia and nitrogen deficiency in faba bean growing areas (Graham and Vance, 2000) because symbiotically effective rhizobia increase nodulation, N-fixation, growth and yield of their host (Graham and Vance, 2000; Kiros Habtegebrial and Singh, 2006). Furthermore, exploiting BNF can be one of the alternatives to enhance soil fertility in Tigray considering the severe land degradation, and unavailability and unaffordability of commercial fertilizers for resource poor farmers.

This reflects the need to study the effect of indigenous rhizobia on nodulation and growth of faba bean to fully realize the role of BNF. However, study on the effect and characteristics of indigenous rhizobia in faba bean production are very scarce (Kiros Habtegebrial and Singh, 2006). Hence, this study was initiated with the aim of studying morphological and physiological characteristics of the indigenous rhizobia, and their effect on nodulation and growth of the crop in the major faba bean producing areas of Tigray.

\section{MATERIALS AND METHODS}

\subsection{Soil Sampling}

Forty-four (44) soil samples were collected from major faba bean growing districts of Tigray (Fig. 1). Soil samples were collected from farmers' field in which faba bean has been grown with no history of inoculation with rhizobia. About $3 \mathrm{~kg}$ of soil samples were randomly taken using sterilized polyethylene bags from a depth of 0-30 cm from the surface of 6 spots of each sampling site. They were mixed, sub-sampled and transported to the laboratory for nodulation test. 


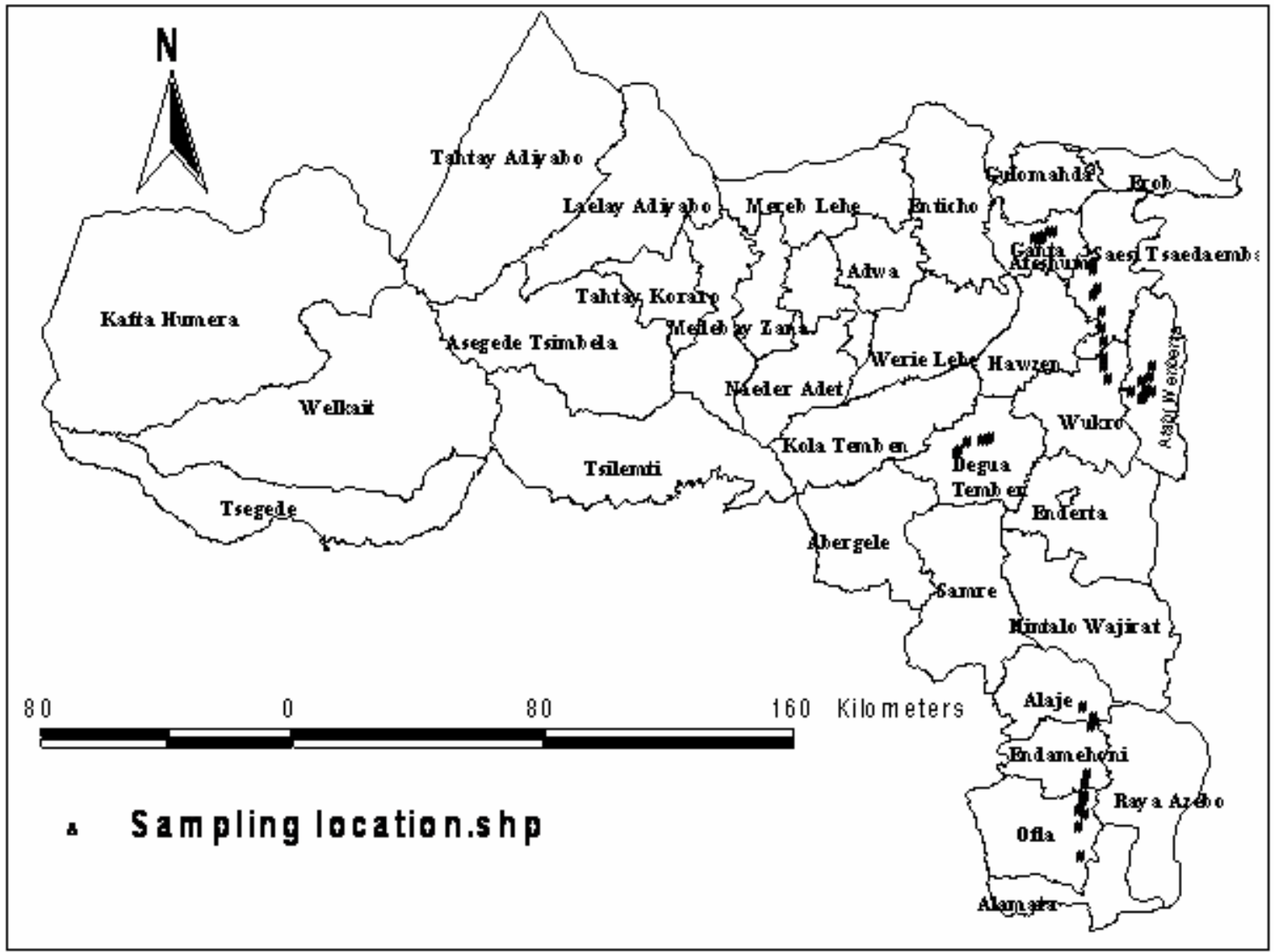

Figure 1. Map of the Soil sampling location in Tigray.

\subsection{The effect of indigenous rhizobia on nodulation and growth of faba bean}

The seeds of variety Degaga of faba bean were used for this experiment according to Vincent (1970). Plastic pots with $3 \mathrm{~kg}$ capacity were surface sterilized with $95 \%$ ethanol by swabbing and filled with each of the homogenized and sieved soil sample using $2 \mathrm{~mm}$ mesh size. The seeds were briefly surface sterilized by soaking them in $95 \%$ ethanol for 10 seconds and $0.1 \%$ acidified mercuric chloride $(5 \mathrm{ml}$ conc. $\mathrm{HCl}$ with $1 \mathrm{~L}$ distilled water) for $4 \mathrm{~min}$. They were repeatedly washed with sterilized distilled water and allowed to germinate on sterile water agar plates (7.5g of agar in 1L water) for 2 days. Four pre-germinated seeds were transplanted to each pot, which were, then, thinned down to 3 after a week. The experiment was done in triplicates and arranged in Randomized Complete Block Design (RCBD). The pots were watered every three days for 45 days. Then after, the plants were gently uprooted from the pots and immersed several times in a container containing $10 \mathrm{~L}$ of water to remove soil particles. Nodule number, 
nodule fresh weights, nodule color, shoots height and leaf colors (yellow, green) were determined from each pot.

\subsection{Rhizobia isolation}

Three nodules were picked up from roots and surface sterilized as before and transferred into sterilized petri dishes to be crushed with flamed glass rod. The extract from nodules was streaked onto pre-dried surface of Yeast Extract Mannitol Agar-Congo red (YMA-CR) plates with pH = 6.8 and incubated at $28^{0} \mathrm{C} \pm 2^{0} \mathrm{C}$. After 5 days, single colonies were picked and purified by repeated plating on YMA plates. The pure isolates were preserved at $4^{0} \mathrm{C}$ on YMA slants containing $0.3 \%(\mathrm{~W} / \mathrm{V}) \mathrm{CaCO}_{3}$ until used (Vincent, 1970).

\subsection{Authentication of the strains}

Presumptive test for rhizobia was conducted before authentication according to Somasegran and Hoben (1994). All the strains were tested for their gram reaction, growth on YMA-CR, cell shape and growth on Glucose-peptone medium. Out of the 44 strains, 12 were selected based on their nodule number and color for further characterization. Each of the selected strains was authenticated as root nodulating bacteria by re-inoculating them on the host as described by Somasegran and Hoben (1994) in glasshouse. Three-kilogram capacity pots were filled with acid washed and heat sterilized $\left(121^{\circ} \mathrm{C}, 151 \mathrm{~b} /\right.$ for $\left.15 \mathrm{~min}\right)$ river sand. As a starter, $20 \mathrm{ppm}$ of $\mathrm{N}$ was included in each pot before planting (Gibson, 1980). Four pre-germinated seeds were transferred into each pot. Each seedling was inoculated with $1 \mathrm{ml}$ of each isolate with an inoculum size of $10^{9}$ cells/ml (Somasegaran and Hoben, 1994).

After a week, the seedlings were reduced into three per pot. Two treatments were used as control: one without inoculation and addition of nitrogen (TN-) and the other un-inoculated but with $0.05 \%(\mathrm{~W} / \mathrm{V}) \mathrm{KNO}_{3}$ per week $(\mathrm{TN}+)$. This experiment was made in triplicates and the plants were grown under glasshouse condition. The pots were arranged in Randomized Complete Block Design (RCBD) and fertilized with quarter strength Broughton and Dilworth N-free medium (Somasegaran and Hoben, 1994). Four weeks after planting, the plants were uprooted and the presence/absence of nodules was recorded (Lupwayi and Haque, 1994).

\subsection{Characterization of the strains}

All of the selected strains were characterized by their morphological and physiological features. All inoculations were standardized with an inoculum size of approximately $10^{4}$ cells $/ 10 \mu$ unless otherwise specified. All tests were carried out in triplicates on YMA. Each plate was spot 
inoculated eight times with $10 \mu \mathrm{l}\left(10^{4}\right.$ cells) of the isolate (Amarger et al., 1997). Except for cultures used to determine the minimum and maximum growth temperature, all inoculated plates were incubated at $28 \pm 2{ }^{0} \mathrm{C}$. Results were recorded after 5 days. Result for growth tests was determined qualitatively and presented as '+' for growth and '-'for no growth.

\subsubsection{Cultural characteristics}

Loop full of test strains were streaked on YMA and incubated at $28 \pm 2^{0} \mathrm{C}$. The plates were checked after 3 days. Colony diameter and morphology were recorded as SD (small dry), LM (large mucoid) or LW (large watery) according to Ahmed et al. (1984). Acid or alkaline production of the strains was detected on YMA containing 0.5\% Bromothymol blue (YMABTB). The strains were grown in $10 \mathrm{ml}$ of YMB approximately $10^{6}$ cells $/ \mathrm{ml}$ and loop full of suspension was streaked on to YMA-BTB. The color change was recorded after three days (Jordan, 1984).

\subsubsection{Physiological characteristics}

Salt tolerance of the strains was assessed by growing them on YMA medium containing 0.5, 1, 1.5 and $2 \%(\mathrm{~W} / \mathrm{V}) \mathrm{NaCl}$. Their tolerance to temperature was assessed at 5, 10, 30, 35, 40 and $45^{\circ} \mathrm{C}$ on YMA. Tolerance to $\mathrm{pH}$ was also tested at $\mathrm{pH}$ of 4, 4.5, 5, 6 and 8.0. Growth was evaluated qualitatively after 5 days (Jordan, 1984; Amarger et al., 1997).

\subsection{Nodulation status survey}

The general survey was carried out in the rainy season when fields were covered with the crop. In most cases, attempts were made to meet the owner of the field to establish cropping history. Nodulation was assessed in the same field; six plants were randomly uprooted using a hand fork to observe the root system. The soil was carefully washed in a container containing water so that the extent of nodulation could be assessed as either good ( $>75$ nodules/root system; pink in color), moderate 25-75 nodules /root system; pink in color) or poor ( $<25$ nodules/root system; pink or white in color or $>25$ nodules white in color) (Amijee and Giller, 1998).

\subsection{Methods of Statistical Analysis}

The results of the sampling sites were compared by analysis of variance and correlation coefficient using SPSS version 12 statistical software. The nodule number, fresh weight and shoot height during isolation for each district was compared with one way ANOVA. Correlation between nodule number, nodule fresh weight and shoot height during isolation and nodulation status, and production was done. 


\section{RESULT}

\subsection{Isolation of the rhizobia and their effect on nodulation and growth}

Rhizobial isolates were obtained from all sampling sites. All isolates fulfilled the characteristics of rhizobia (Lupwayi and Haque, 1994): gram-negative, rod-shaped; did not absorb Congo red; and did not grow well on glucose-peptone medium. Our data showed variation among faba bean producing areas in terms of nodule number, nodule fresh weight, and nodule color (Table. 2). Statistically significant differences were also observed in nodule number, nodule fresh weight and shoot height at $\mathrm{p}<0.05$ (Table. 2). The highest average nodule number, fresh weight and shoot height were observed from Ofla district (96 nodules/ plant, $1.13 \mathrm{gm}, 41.3 \mathrm{~cm}$, respectively).

Table 2. The effect of indigenous rhizobia on nodulation and shoot height of faba bean.

\begin{tabular}{|ccccc|}
\hline District & $\begin{array}{c}\text { Nodule number/plant } \\
\text { root system }\end{array}$ & $\begin{array}{c}\text { Nodule fresh } \\
\text { weight }(\mathrm{gm}) / \text { plant }\end{array}$ & Nodule Color & $\begin{array}{c}\text { Shoot } \\
\text { height }(\mathrm{cm})\end{array}$ \\
Alaje & $79^{\mathrm{ab}}$ & $1.03^{\mathrm{ab}}$ & $\mathrm{P}$ & $35^{\mathrm{b}}$ \\
Ofla & $96^{\mathrm{a}}$ & $1.13^{\mathrm{a}}$ & $\mathrm{P}$ & $41.3^{\mathrm{a}}$ \\
G/ Afeshum & $60^{\mathrm{ab}}$ & $0.74^{\mathrm{bc}}$ & $\mathrm{W}$ & $26.5^{\mathrm{c}}$ \\
S/ Emba & $39^{\mathrm{bc}}$ & $0.75^{\mathrm{bc}}$ & $\mathrm{W}$ & $27.3^{\mathrm{c}}$ \\
D/Temben & $60^{\mathrm{ab}}$ & $1.02^{\mathrm{ab}}$ & $\mathrm{W}$ & $33.3^{\mathrm{b}}$ \\
A/Wenberta & $55^{\mathrm{abc}}$ & $1.00^{\mathrm{ab}}$ & $\mathrm{W}$ & $28.7^{\mathrm{c}}$ \\
K/Awlalo & $16^{\mathrm{c}}$ & $0.53^{\mathrm{c}}$ & $\mathrm{P}$ & $29^{\mathrm{c}}$ \\
\hline
\end{tabular}

Means with same letter do not show statistically significant difference at $\mathrm{p}<0.05$.

Where: $\mathrm{P}=$ pink, $\mathrm{W}=$ White

Weak plant vigor (short and yellow leaf) and white nodules were recorded more frequently from G/Afeshum, S/emba and A/Wenberta. White nodule seems partly responsible for weak vigor in these areas. Moreover, the nodule number was also positively correlated with shoot height $(\mathrm{r}=$ $0.342, \mathrm{p}<0.05)$ and strongly correlated with the production $(\mathrm{r}=0.742, \mathrm{p}<0.01)$. There was also correlation between nodule fresh weight $(\mathrm{r}=0.477)$ and shoot height $(\mathrm{p}<0.01)$.

\subsection{Authentication and characterization of the strains}

A total of twelve strains were selected from the districts based on their effective symbiotic characteristics. All of them induced nodules on the host plant in glasshouse. More than half of the strains $(\mathrm{n}=7)$ displayed large mucoid (LM) colonies with 2-4 mm diameter, except MUFR29, MUFR40, MUFR44, MUFR54, MUPR59 which were characterized by large watery (LW) appearance on YMA medium (Table. 3). All strains turned the YMA-BTB medium into yellow after 3 days of incubation. 
Table 3. Cultural and physiological characteristics of the strains.

\begin{tabular}{|c|c|c|c|c|c|c|c|c|c|c|c|c|c|c|c|c|c|}
\hline \multirow[t]{3}{*}{ Isolates } & \multirow[t]{3}{*}{ District } & \multicolumn{16}{|c|}{ characteristics } \\
\hline & & \multicolumn{3}{|c|}{$\begin{array}{l}\text { Cultural } \\
\text { characteristics }\end{array}$} & \multirow{2}{*}{$\begin{array}{l}\text { Salt } \\
(\mathbf{w} / \mathbf{v}) \\
0.5\end{array}$} & \multicolumn{3}{|c|}{ tolerance } & \multicolumn{4}{|c|}{$\begin{array}{l}\text { Temperature } \\
\text { tolerance }\left({ }^{\circ} \mathrm{C}\right)\end{array}$} & \multicolumn{5}{|c|}{ pH tolerance } \\
\hline & & $\mathrm{D}$ & M & YMA-BTB & & 1 & 1.5 & 2 & 5 & 10 & 40 & 45 & 4.5 & 5 & 5.5 & 6 & 8 \\
\hline MUFR1 & Alaje & 2.5 & LM & Y & - & - & - & - & - & + & - & - & - & - & - & + & + \\
\hline MUFR16 & // & 3 & LM & Y & + & + & + & + & - & + & + & - & - & - & + & + & + \\
\hline MUFR20 & Ofla & 4 & LM & Y & + & + & + & + & - & - & + & - & _- & - & - & + & + \\
\hline MUFR24 & // & 2 & LM & Y & + & + & + & + & - & - & + & - & - & - & + & + & - \\
\hline MUFR29 & G/Afeshum & - & LW & Y & + & + & + & + & - & + & + & + & + & - & - & + & + \\
\hline MUFR33 & // & 3 & LM & Y & + & + & + & + & - & + & + & - & - & - & - & + & + \\
\hline MUFR37 & T/Emba & 4 & LM & Y & + & + & + & + & + & + & + & - & - & - & + & + & + \\
\hline MUFR40 & $\mathrm{D} /$ Temben & 2 & LW & $\mathrm{Y}$ & - & - & - & - & - & + & + & - & + & - & + & + & + \\
\hline MUFR44 & // & & LW & Y & + & + & + & + & + & + & + & - & - & - & + & + & + \\
\hline MUFR54 & A/Wenbeta & 2 & LW & Y & + & + & - & - & + & + & + & - & - & + & + & + & + \\
\hline MUFR49 & // & 2.5 & LM & $\mathrm{Y}$ & - & + & + & + & - & + & + & - & - & - & + & + & + \\
\hline MUFR59 & K/awlalo & 2 & LW & Y & + & + & + & + & - & - & + & - & - & + & + & + & + \\
\hline
\end{tabular}

Note: $\mathrm{LM}=$ large mucoid; $\mathrm{LW}=$ large watery, $\mathrm{Y}=$ yellow, "+"= growth, “-“= no growth

Most of the strains were able to grow on all tested $\mathrm{NaCl}$ concentrations (Table. 3). The most sensitive strains which did not grow on all tested $\mathrm{NaCl}$ concentrations were MUFR1 and MUFR40. MUFR54 grew on $0.5 \%$ and $1 \%$ but not at $1.5 \%$ and $2 \%(\mathrm{w} / \mathrm{v}) \mathrm{NaCl}$. Almost all strains were found to grow at $\mathrm{pH}$ 6.0-8.0, with the exception of MUFR24 that failed to grow at high $\mathrm{pH}$ (8.0). Although only MUFR54 and MUFR59 grew at $\mathrm{pH} 5.0$, most of them were found to grow at $\mathrm{pH}$ 5.5. Most strains, 75 and $91.6 \%$ were unable to grow at 5 and $45^{\circ} \mathrm{C}$. Strains that grew at $5^{\circ} \mathrm{C}$ were MUFR37, MUFR44 and MURR54. MUFR29 was the only strain that could grow at $45^{\circ} \mathrm{C}$.

\subsection{Nodulation status of the crop}

Our field observation showed that faba bean was cultivated by smallholder farmers who grew as a sole. It involves in crop rotation system used by these farmers to enhance soil fertility. Fields covered with legume crop last growing season were replaced by cereals during the survey. Although root nodulation of faba bean by indigenous population of rhizobia was observed, field crop across sampled fields showed great variation in nodulation status (nodule number and color) 
(Table. 4). This difference was not only limited across the districts but also within each district (data is not presented). Nodulation status was rated as good ( $>100$, pinkish) in Ofla; moderate (25-75 nodules, pinkish) in Alaje and D/Temben; and poor (predominantly white nodules) in G/Afeshum, S/Emba and A/Wenberta though nodule number was high. In K/Awlalo nodules were predominantly pink but the number was low at many sites (Fig.2; Fig 3). There was strong correlation between nodulation status $(\mathrm{r}=0.814)$ of the crop and the yield of the crop in the districts $(\mathrm{p}<0.05)$.

Table 4. Nodulation status of the field crops in the districts.

\begin{tabular}{|lll|}
\hline District & Nodulation & Remarks \\
Alaje & Moderate & An average of 66 nodules, pink at many places. \\
Ofla & Good & High average nodule number with pinkish nodules. \\
G/Afeshum & Poor & Nodules were predominantly white at most places. \\
S/Emba & poor & Nodules were whitish. \\
D/ Temben & Moderate & An average of 62 nodules, pink at many places. \\
A/ Wenberta & Poor & At most of the sites nodules were white in color. \\
K/ Awlalo & Poor & Nodules were $<25$ but predominantly pinkish. \\
\hline
\end{tabular}

Note: Good $=\geq 75$ nodule/ root system, pink; moderate $=25-75$ nodule/ root system, pink; Poor $=<$ nodules/root system, pink or 25 nodules/root system but white in color.
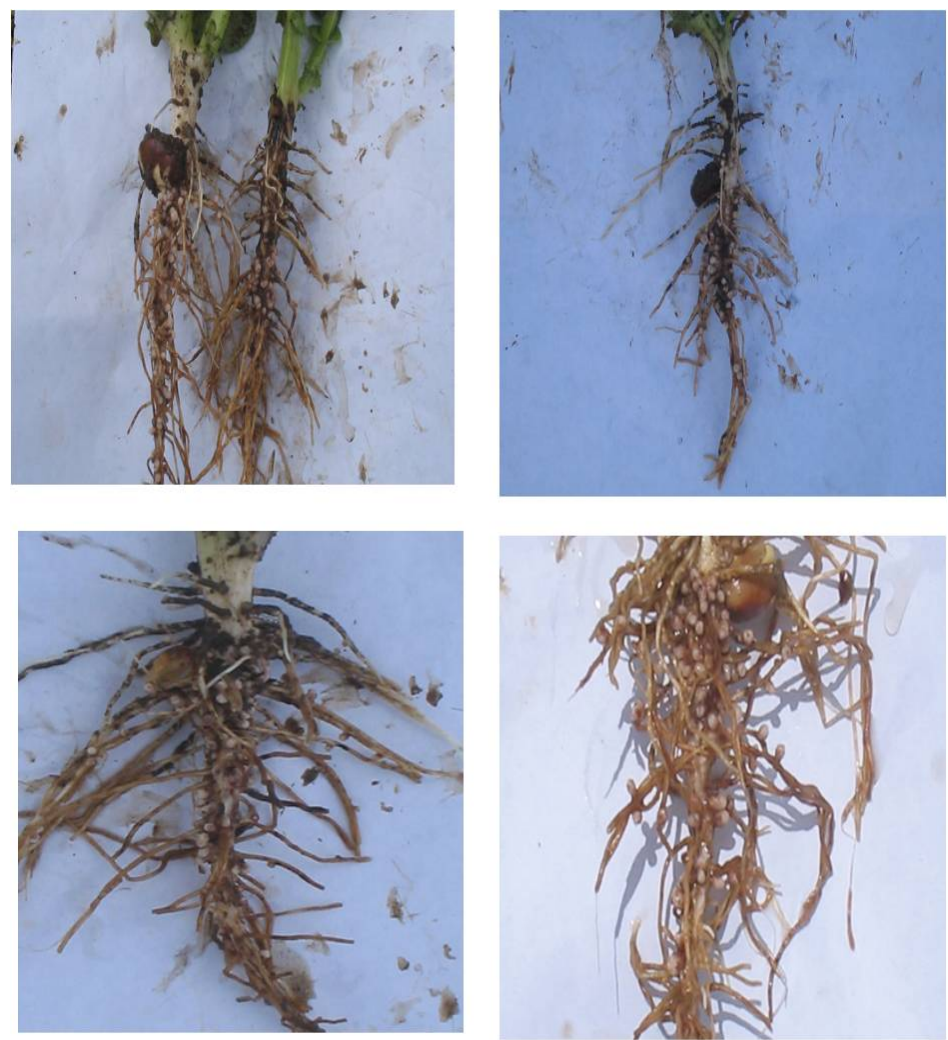

Figure 2. Sample of nodulation from Ofla district (good nodulation status). 

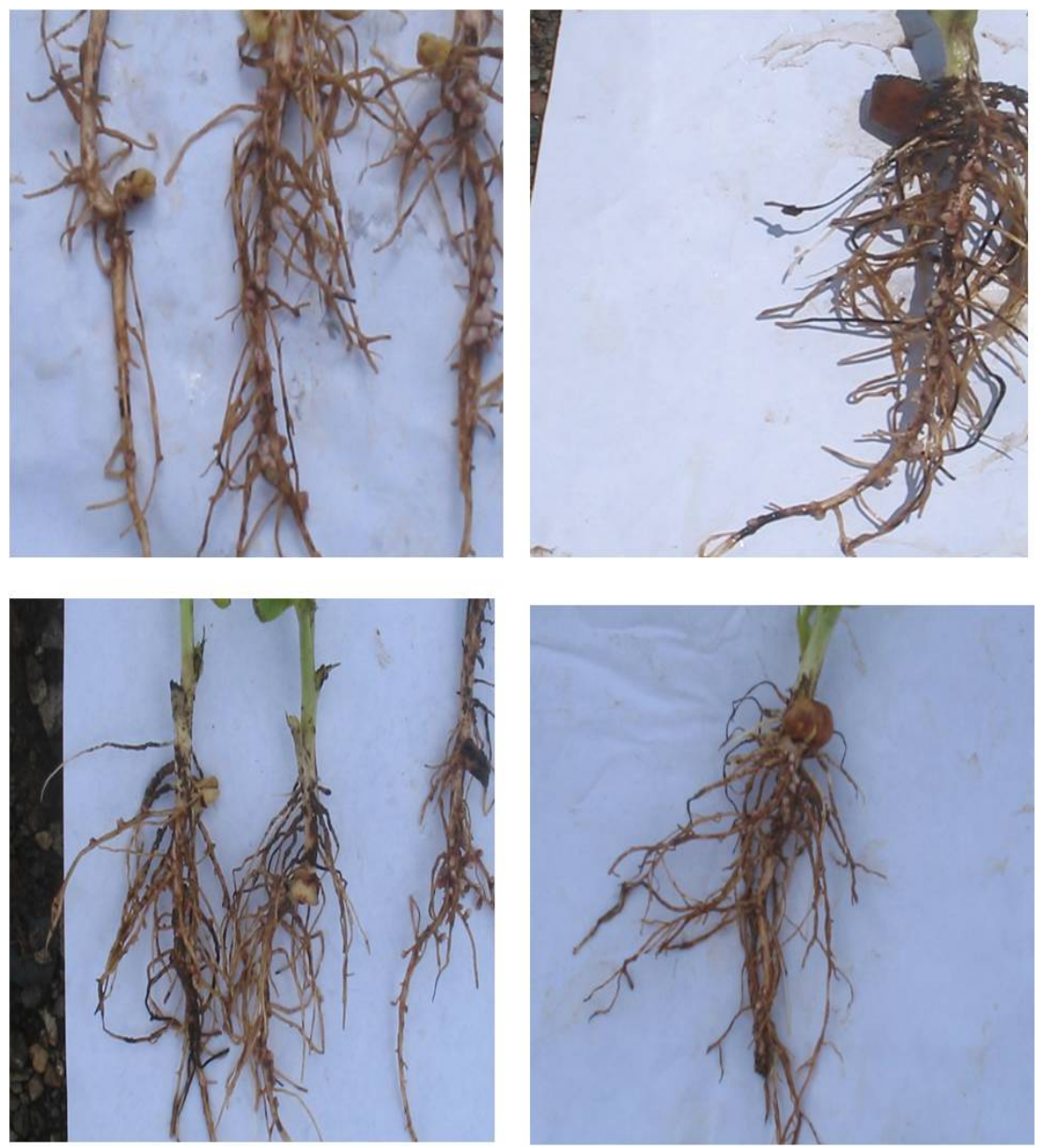

Figure 3. Nodulation from G/ Afeshum district (poor nodulation status).

\section{DISCUSSION}

\subsection{Isolation and characteristics of the strains}

The result of this study showed that indigenous rhizobial strains were present in all sampled soils. Different researchers also isolated rhizobial strains nodulating faba bean from Ethiopian soils (Desta Beyene and Angaw Tsigie, 1987; Aynababa Adamu et al., 2001). Our strains fall into fast growing rhizobia based on acid production and large growth with production of copious exopolysaccharide (Jordan, 1984). However, there was variation in their morphological and physiological characteristics.

Similarly, Rhizobium leguminosarum var viceae was identified as fast growing bacteria nodulating faba bean in several studies (Jordan, 1984; Aynabeba et al. 2001). Aynabeba et al. 
(2001) reported that among the many strains isolated from each sampling field in Semen Shewa, all the strains were fast growing and acid producing similar to the type strain.

Rhizobium leguminosarum var viceae was revealed abundant diversity in their morphological and physiological characteristics (Jordan 1984; Aynabeba et al., 2001). The presence of strains growing under stressed laboratory conditions $\left(2 \% \mathrm{NaCl}, 5\right.$ and $45^{\circ} \mathrm{C}, \mathrm{pH}$ of 5 and 8$)$ in this study indicates their significance in contributing biologically fixed nitrogen to stressful ecosystems. This shows the possibility of screening tolerant strains from the soil where they are naturally selected (O'Hara et al., 2002). The presence of tolerant strains becomes more interesting since the selected strains are good at nodulation and plant growth. This shows the possibility of getting effective stress tolerant strains through rigorous screening and characterization to exploit BNF in the low-input agricultural systems of Tigray.

\subsection{Effect on nodulation and growth of faba bean}

The nodulation status survey indicated that farmers are traditionally exploiting BNF in Tigray. However, the result of rhizobial isolation indicated that there was wide variation in nodule number, nodule fresh weight, nodule color and shoot height. Similarly, in almost all districts except Ofla, Alaje and D/Temben nodulation status was characterized as poor according to the method used by Amijee and Giller (1998). Studies indicated that variation in nodulation could be due to low rhizobial density, incompatibility of the rhizobia and edaphic factors that hinder the effectiveness of the rhizobia (Zaharan, 1999; Slattery and Pearce, 2002; Kiros Habtegebrail and Singh, 2006).

Related result was also observed in the "yield depleted" areas of Semen Shewa where low population of rhizobia was one of the factors for poor nodulation and N-fixation (Aynababa Adamu et al., 2001). Though large number of diverse rhizobial strains were present in the soil, only a few of them were effective in nitrogen accumulation (Aynababa Adamu et al., 2001). Desta Beyene and Angaw Tsiegie (1987) isolated faba bean rhizobia from several pulse growing areas of central Ethiopia and they found only 23 symbiotically effective strains from 108 isolates.

Poor nodulation at most sites in our study might indicate that it could have its contribution for poor plant growth and low yield of faba bean. Poor nodulation generally produced low grain yields while good nodulation increases N-fixation, growth and yield (Fomeg-As, 2004). Hence, the coincidence between poor nodulation of the crop and low average yield of the districts in this 
study (Table.1) may indicate the association between yield and nodulation status (Table. 2 and Table. 4). Ofla district with good nodulation (Table. 2; Table. 4; Fig. 2) and relatively better yield in all years (Table. 1) strengthen the conclusion that poor BNF may partly be responsible for yield reduction of faba bean in Tigray.

Yield reduction can be improved through inoculation of adaptable effective rhizobia which improve nodulation and yield (Lupwayi and Mkandawire, 1996; Aynababa Adamu et al., 2001; Kiros Habtegebrail and Singh, 2006). Therefore, field inoculation trail, survey on environmental factors responsible for poor nodulation and count on number of indigenous rhizobial populations are recommended for further exploitation of BNF.

\section{ACKNOWLEDGEMENT}

I acknowledge NORADII project for financial support. The supply of seeds by Holeta Agricultural Research Center and data on production in Tigray by Tigray Bureau of Agriculture are highly appreciated. I am grateful to Professor Mitiku Haile for his support and encouragement during the study. I am also grateful to my colleagues especially Getachew Giday, Gebru Equar and Mihiret Hadgu for their help in the lab and field works. Last but not least, I acknowledge Solomon Hishe and Biadglegn Desmisse for GIS data processing.

\section{REFERENCE}

Ahmed, M., Rafique Uddin, M \& Mc Langhlin, W. 1984. Characterization of indigenous rhizobia from wild legumes. FEMS Microbiology Letter, 24: 197-203.

Amanuel G., Kuhne, R., Tanner, D \& Vlek, P. 2000. Biological N fixation in faba bean (Vicia faba) in the Ethiopian highlands as affected by $\mathrm{P}$ fertilization and inoculation. Biology and Fertility of Soils, 32: 353-359.

Amarger, N., Macheret, V \& Laguerre, G. 1997. Rhizobium gallicum sp. Nov. and Rhizobium giardinii sp. Nov from Phaseolus vulgaris nodules. International Journal of Systematic Bacteriololgy, 47: 996-1006.

Amijee, F \& Giller, K.E. 1998. Environmental constraints to nodulation and nitrogen fixation of Phaseolus vulgaris L. in Tanzania, I. A survey of soil fertility, root nodulation and Multilocational responses to rhizobium inoculation. African Crop Science, 6: 159-169.

Asfaw Tilaye, 1985. Faba bean in Ethiopia. FABIS, Newsletter, 12: 3-4. 
Asfaw Tilaye, Geletu Bejiga \& Alem Berhe. 1994. Role of cool season food legumes and their production constraints in Ethiopian agriculture. In: Asfaw Telaye, Geletu Bejiga, M. Saxen and M. Solh, (Eds.), Cool-season Legumes of Ethiopia. International center for Agricultural Research in Dry Areas, Addis Ababa, Ethiopia, 3-19 pp.

Aynabeba Adamu, Fassil Assefa, Asfaw Hailemariam \& Endashaw Bekele. 2001. Studies of Rhizobium inoculation and fertilizer treatment on growth and production of faba bean (Vicia faba) in some yield depleted and yield sustained regions of Semien Showa. SINET: Ethiopian Journal of Science, 24:197-211.

Danso, S.K.A. 1992. Biological nitrogen fixation in tropical agro systems. Twenty years of biological nitrogen fixation in Africa. In: K. Mulogoy, M. Guye and D.S.C. Spence (Eds.), Biological nitrogen fixation and sustainability of tropical agriculture. Proceedings of the $4^{\text {th }}$ International Conference of Africa Association for Biological nitrogen fixation (AABNF) held at International Institute of Tropical Agriculture. John Wiley and Sons, Chichester, New York, Toronto, 336-362 pp.

Desta Beyene \& Angaw Tsigie. 1987. The response of pulse crops to N and P fertilizers. In: Soil Science Research. Proceedings of the first soil science research review workshop, Addis Ababa, Ethiopia, 11-14 Feb.

EARO (Ethiopian Agricultural Research Organization). 2000. Lowland pulses research strategy. EARO, Addis Ababa, Ethiopia, 1-39 pp.

Fomeg-As, D. Y. 2004. Multi-farm trial of Biological Nitrogen Fixation (BNF) in Beans (Phaseolus vulgaris) at Mountain Province. Presented during the regional sectoral/ commodity review, ATI-CAR, BSU cmpd, La Trinidad, Bengueton, June 15-17.

Gibson, A. 1980. Methods for legumes in glasshouse and controlled environmental cabinets. In: F. Bergersen (Ed.), Methods for Evaluating Biological Nitrogen Fixation. WileyInterscience Publication, John Wiley \& Sons, NewYork, 139-184 pp.

Graham, P \& Vance, C. 2000. Nitrogen fixation in perspective: an overview of research and extension needs. Field Crops Research, 65: 93-106.

Hawitin, G. C \& Hebblewaite, P. D. 1993. Background and history of faba bean production. In: P. Hebblewate (Ed.), The faba bean (Vicia faba), Butter worth's, London, 1-21 pp.

Jordan, D. 1984. Rhizobaceae. In: D.P. Hendricks, H.A. Sneath and J.H. Halt (Eds.), Bergey's Manual of Systematic Bacteriology, 2: 234-256. 
Kiros Habtegebrial \& Singh, B.R. 2006. Wheat responses in semiarid northern Ethiopia to N2 fixation by Pisum sativum treated with phosphorus fertilizers and inoculants. Nutr Cycl Agroecosystem, 75: 247-255.

Lupwayi, N \& Haque, I. 1994. Legume-Rhizobium Technology Manual. Environmental Sciences Division International Livestock Center for Africa. Addis Ababa, Ethiopia. 1-93 pp.

Lupwayi, N \& Mkandawire. 1996. Short communication: phosphorus, sulphur and molybdenum effects on response of Phaseolus beans to inoculation with Rhizobium in Malawi. African Crop Science, 4: 359-364.

O' Hara, G., Yates, R \& Howiesen, J. 2002. Selection of strains of root nodule bacteria to improve inoculant performance and increase legume productivity in stressful environments. In: D. Herridge (Ed.), Inoculants and Nitrogen Fixation of Legumes in Vietnam.

Slattery,J \& Pearce, D. 2002. The impact of background rhizobial populations on inoculant response. In: D. Herridge, (Ed.), Inoculants and Nitrogen Fixation of Legumes in Vietnam.

Somasegaran, P \& Hoben, H. 1994. Hand book for Rhizobia. Springer- Verlang, New York, 1$138 \mathrm{pp}$.

Vincent, J.M. 1970. A manual for the practical study of Root Nodule Bacteria, Oxford, 1-166 pp.

Zaharan, H. 1999. Rhizobium-legume symbiosis and nitrogen fixation under severe conditions and in an arid climate. Microbiology and Molecular Reviews, 63: 968-989. 